\title{
Isolation, identification and antibiotic resistance of Vibrio alginolyticus isolated from Mugil seheli - Suez Governorate, Egypt
}

Khafagy A. A. R. ${ }^{1}$, Aida. A. Farag², Mohamed. S. Ibrahim³, Reham. A. Ibrahim $^{3}$

1- Department of Bacteriology, Immunology and Mycology, Faculty of veterinary Medicine, Suez Canal University.

2- Biotechnology Lab, Marine Environmental Division, National Institute of Oceanography and Fisheries (NIOF), Alexandria.

3- Microbiology Lab, Marine Environmental Division, National Institute of Oceanography and Fisheries (NIOF), Alexandria.

Received: March 10, 2018; Accepted: March 29, 2018 Vol.8 (2):1-16

\begin{abstract}
Vibrio alginolyticus was isolated from Mugile seheli collected from private farm in Suez Governorate. Clinically examined fish exhibited dark colouration, erosions and haemorrhages of body parts. The target organs for isolation were kidney (52\%), liver (48\%) and spleen (15\%). Isolates were biochemically and molecularly identified using species specific primers targeting collagenase gene and tdh gene. Investigation revealed that, 17 isolates were identified as V.alginolyticus which detected at 737 bp fragment, and only one positive amplicon for tdh gene that was detected at $373 \mathrm{bp}$ fragment. The sequence results of V.alginolyticus isolate showed $99 \%$ identity with the reference strain V.alginolyticus reported on Gene Bank with accession number (MG271844). The antibiotic sensitivity test of virulent strain of $V$. alginolyticus showed that, the bacterium was highly resistant to lincomycin $2 \mu \mathrm{g}$, streptomycin $10 \mu \mathrm{g}$, ampicillin $10 \mu \mathrm{g}$, trimethoprim $5 \mu \mathrm{g}$ and ampicillin/ sulbactam combination, and intermediate sensitivity to Naldixic acid $30 \mu \mathrm{g}$, polymyxin B $300 \mathrm{u}$, erythromycin $15 \mu \mathrm{g}$, Tobramycin $10 \mu \mathrm{g}$, ciprofloxacin $5 \mu \mathrm{g}$, kanamycin $30 \mu \mathrm{g}$ and chloramphenicol $30 \mu \mathrm{g}$. It was also found that, the bacterium was highly sensitive to imipenem $10 \mu \mathrm{g}$, Oxolonic acid $2 \mu \mathrm{g}$, oxytetracyclin $30 \mu \mathrm{g}$, gentamycin $10 \mu \mathrm{g}$, gatifloxacin $5 \mu \mathrm{g}$ and piperacillin/ tazobactam combination.
\end{abstract}

Key words: Vibrio alginolyticus, Suez Governorate, Virulent gene, Antibiotic resistance 


\section{Introduction}

Mugil Seheli belongs to family Mugilidae that consists around the world of more than 72 species from 17 fish genera. It is one of the commercially important fish species in Suez Bay and Egypt, although it has a lower growth rate, fetches a higher market price compared to the other mullet in Egypt because of its highly appreciated taste (Nelson, 2006). Farmed fish are more susceptible to disease agents than wild fish due to their intensive rearing conditions (Salinas et al., 2006). And bacterial diseases are considered one of the most important problems facing fish industry, that are responsible for heavy mortality not only in cultured fish but also in wild too and affect badly the economics since the beginning of marine fish culture (Khalil and Abd El-Latif 2013). The majority of bacterial diseases in aquaculture production system are caused by some causative agents include bacteria from short, Gram-negative rods belonging to the families Enterobacteriaceae, Pseudomonadaceae (Pseudomonas) and Vibrionaceae (Vibrios) (Aly, 2009 and Barbosa et al., 2011). And Vibrionaceae is a large and complex group of marine bacteria that can significantly affect the health of aquatic animals (Carson et al., 2009) and some Vibrio species are pathogenic for fish, eels and frogs as well as other vertebrates and invertebrates (Todar, 2005). Antibiotic susceptibilities differ between species but almost all strains are sensitive to chloramphenicol, tetracycline, and quinolones. However, some strains of $V$. alginolyticus are sometimes multiply resistant to these antibiotics including chloramphenicol, tetracycline and cefotaxime.(Musa and Wei 2008; Costinar et al., 2010; Ransangan, et al., 2013 and Younes et al., 2016). But the use of antibiotics and disinfectants not only for disease control but also for the improvement of growth and efficiency of feed conversion have been found to have a negative impacts in aquaculture such as the development of bacterial resistant, the change of microbial composition in ecosystem and residual antibiotics or disinfectants in aquaculture products and thus the appearance of multiple antibiotic resistance (MAR) (Levy, 2001; Cabello, 2006 and Esposito et al., 2007).So, this study was planned for isolation of $V$. alginolyticus from Mugile Seheli collected from private farm in Suez Governorate with phenotypic and molecular characterization of the isolated species. Furthermore, to investigate the 
antibiotic susceptibilities of isolates against the most common antibiotics used for controlling of Vibrio infection

\section{Materials and methods}

\section{Fish samples:}

A total of twenty five (25) of naturally infected Mugil Seheli collected from private farm in Suez Governorate. The collected fish samples were submitted directly to the laboratory for clinical and bacteriological examination (Buller, 2004; Austin and Austin, 2012).

\section{Clinical and postmortem examination:}

External and internal examination of fish samples were performed to record clinical abnormalities according to (Austin and Austin, 2012 and Noga and Dvm 2010).

\section{Bacteriological examination:}

An inoculum from kidney, spleen and liver samples were taken under complete aseptic conditions and inoculated into TSB with $2 \% \mathrm{NaCl}$ then a loopful of bacterial suspension was re-streaked over TCBS (Thiosulphate Citrate Bile Salt Agar, OXOID) plates. All plates were incubated at $28{ }^{\circ} \mathrm{C}$ for $18-24 \mathrm{hr}$. then a single colony from each suspected isolate was picked up and re-streaked on a new plate of TCBS culture media and re-incubated at the same conditions for purification. Ordinary biochemical identification of bacterial isolates was performed using Gram's stain, oxidase, catalase and IMVC tests followed by Analytical Profile index 20NE (Biomerieux) (Buller, 2004). The purified strains were stored in BHI with $15 \%$ (vol/ vol) glycerol at -20 ${ }^{\circ} \mathrm{C}$.

\section{Molecular identification and Partial sequences of 16SrRNA gene:}

The retrieved Vibrio species were cultured on tryptic soya agar with $2 \%$ $\mathrm{NaCl}$ for genomic DNA extraction according to QIA amp DNA mini kit instructions. The reaction for PCR amplification of each sample was performed in a total volume of $25 \mu$ l containing: $12.5 \mu 12 \mathrm{X}$ Dream Taq Green buffer, $5.5 \mu \mathrm{l}$ PCR grade water, $1 \mu \mathrm{l}$ of each primer $(20 \mathrm{pmol})$ and $5 \mu 1$ Template DNA. Internal fragment of the 16SrRNA gene was amplified using primer sets designed by (Tarr et al., 2007). Collagenase gene was used for species specific detection of $V$. alginolyticus, (Mustapha et al., 2013). tdh gene was used for confirming the pathogenicity of $V$. alginolyticus isolates (Abu-Elala $\boldsymbol{e t}$ al., 2016). The primer sets and the cycling conditions used in this study 
are described in (Tables 1 and 2). The amplified fragment of 16SrRNA gene of Vibrio species were sequenced using MEGA5 program for checking purity and blasted at the NCBI BLAST home page (https://blast.ncbi.nlm.nih.gov/Blast/).

\section{Antimicrobial susceptibility test of the suspected isolate:}

Screening of antimicrobial susceptibility of the bacterial isolates was tested using the standard disk diffusion method (Kirby Bauer test). The test performed on Mueller-Hinton agar (Oxoid) according to the instruction of Clinical Laboratory Standards Institute (CLSI, 2012).

\section{Results}

\section{Clinical signs and Necropsy findings of naturally infected fish:}

Clinically infected fish showed dark coloration of skin with detached scales, Hemorrhages at the base of the fin and some fishes showed eroded fins. Postmortem findings revealed hemorrhagic, friable liver and congested kidney (Fig. 1)

\section{Bacteriological Examination:}

Large, greenish yellow colonies of $V$. alginolyticus were observed on TCBS agar plates. The bacterial isolates were Gram-negative; short comma shaped curved rods, motile, oxidase and catalase positive. Biochemical identification of $V$. alginolyticus isolates by API (20NE) revealed about $99.1 \%$ probability with a code of (7447444).

Table (1): Identification of V.alginolyticus by biochemical test:

\begin{tabular}{cc}
\hline Test & Reaction \\
\hline Oxidase test & Positive \\
Catalase test & Positive \\
Indole test & Positive \\
Methyl red test & Positive \\
Vogus Proskauer & Negative \\
Citrate test & Positive \\
\hline
\end{tabular}


Table (2): showing the API profile of V.alginolyticus

\begin{tabular}{cc}
\hline Biochemical test & V.alginolyticus \\
\hline NO3 & + \\
TRP & + \\
GLU & + \\
ADH & - \\
URE & - \\
ESC & + \\
GEL & - \\
PNPG & - \\
GLU) & + \\
ARA & + \\
MNE & + \\
MAN & + \\
NAG & - \\
MAL & - \\
GNT & - \\
CAP & + \\
ADI & - \\
MLT & - \\
CIT & + \\
PAC & - \\
\hline
\end{tabular}

\section{Molecular identification and partial sequences of 16SrRNA gene:}

The PCR produce specific and identical amplicons to the size of the target gene sequence. In particular, electrophoresis of the partial gene sequence of 16SrRNA gene produce amplicons at $663 \mathrm{bp}$. PCR amplifications of partial gene sequence of collagenase gene of $V$. alginolyticus, were observed at 737 bp, (Fig. 2). The obtained sequences of 16SrRNA gene were blasted with the highly similar sequences in the Gene Bank database of National Center for Biotechnology Information Center (NCBI). The sequencing results revealed that sequences of $V$. alginolyticus isolates showed a close relationship with almost $99 \%$ identity with the reference strains of $V$. alginolyticus reported on Gene Bank .The obtained nucleotide sequences were submitted with accession number (MG271844) in the Gene Bank. 
Table (3): The primer sets used in this study

\begin{tabular}{lllll}
\hline Gene & primer & Sequence & Amplified product & Reference \\
\hline 16SrRNA & V.16S-700F & CGGTGAAATGCGTAGAGAT & $663 \mathrm{bp}$ & Tarr et al., 2007 \\
& V.16S-1325R & TTACTAGCGATTCCGAGTTC & & Mustapha et al., 2013 \\
Tdh & F .tdh & CCATCTGTCCCTTTTCCTGC & $373 \mathrm{bp}$ & Abu-Elala et al., 2016 \\
& R.tdh & CCAAATACATTTTACTTGG & & \\
$\begin{array}{l}\boldsymbol{V} \text {. } \text { alginolyticus } \\
\text { Collagenase }\end{array}$ & Collagenase F & CGAGTACAGTCACTTGAAAGCC & $737 \mathrm{bp}$ & \\
\hline
\end{tabular}

Table (4): cycling conditions of used primer

\begin{tabular}{|c|c|c|c|c|c|c|}
\hline \multirow[t]{2}{*}{ Gene } & \multirow{2}{*}{$\begin{array}{l}\text { Initial } \\
\text { denaturati } \\
\text { on }\end{array}$} & \multicolumn{2}{|c|}{ Amplification } & \multirow[b]{2}{*}{ Extension } & \multirow[b]{2}{*}{ No. of cycles } & \multirow[t]{2}{*}{ Final extension } \\
\hline & & $\begin{array}{l}\text { Secondary } \\
\text { denaturation }\end{array}$ & Annealing & & & \\
\hline \multirow[t]{2}{*}{ 16SrRNA } & $94^{\circ} \mathrm{C}$ & $94^{\circ} \mathrm{C}$ & $56^{\circ} \mathrm{C}$ & $72^{\circ} \mathrm{C}$ & 35 & $72^{\circ} \mathrm{C}$ \\
\hline & $5 \mathrm{~min}$. & $30 \mathrm{sec}$. & $45 \mathrm{sec}$. & $45 \mathrm{sec}$. & & $10 \mathrm{~min}$. \\
\hline \multirow[t]{2}{*}{ tdh gene } & $94^{\circ} \mathrm{C}$ & $94^{\circ} \mathrm{C}$ & $54^{\circ} \mathrm{C}$ & $72^{\circ} \mathrm{C}$ & 35 & $72^{\circ} \mathrm{C}$ \\
\hline & $5 \mathrm{~min}$. & $1 \mathrm{~min}$. & $1 \mathrm{~min}$. & $1 \mathrm{~min}$. & & $10 \mathrm{~min}$. \\
\hline \multirow[t]{2}{*}{ V. alginolyticus Collagenase } & $94^{\circ} \mathrm{C}$ & $94^{\circ} \mathrm{C}$ & $50^{\circ} \mathrm{C}$ & $72^{\circ} \mathrm{C}$ & 35 & $72^{\circ} \mathrm{C}$ \\
\hline & $5 \mathrm{~min}$. & $1 \mathrm{~min}$. & $1 \mathrm{~min}$. & $1 \mathrm{~min}$. & & $10 \mathrm{~min}$. \\
\hline
\end{tabular}




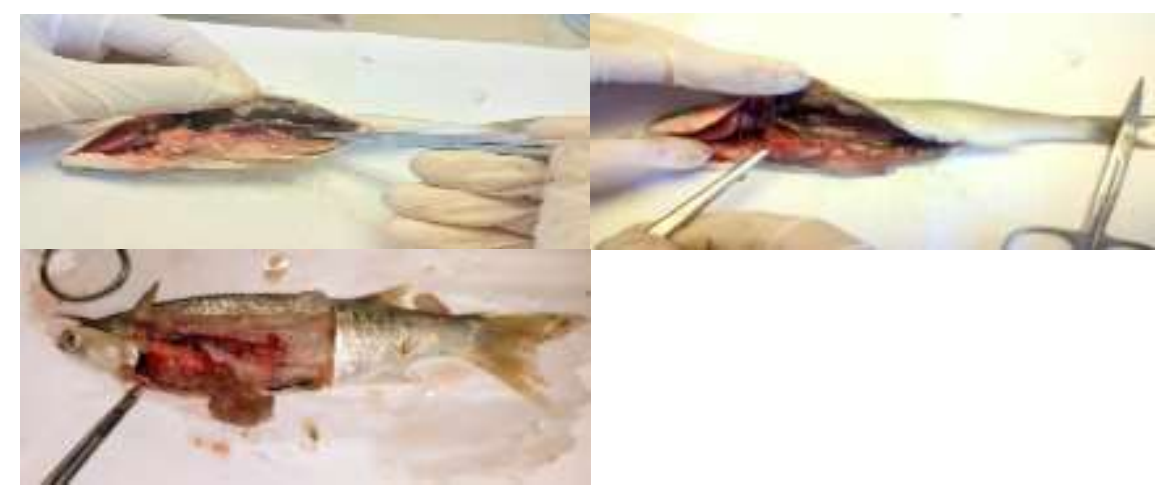

Fig. 1: Necropsy Findings in naturally infected Mugil Seheli showing congested kidney and lacerated and congested liver.
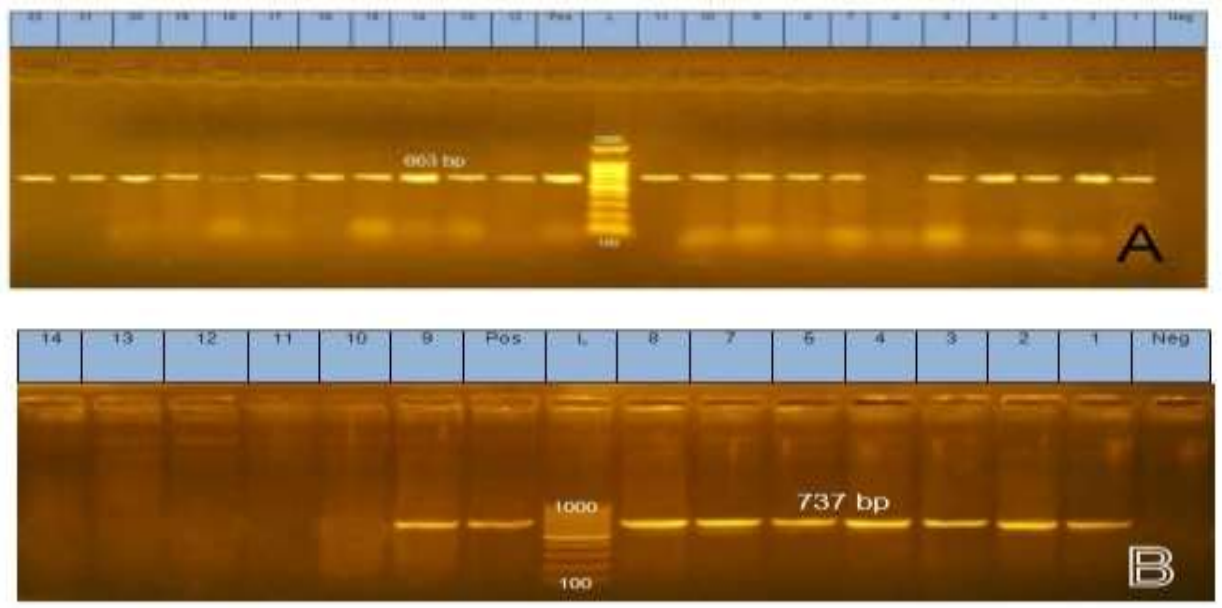

Fig 2: Ethidium bromide stained agarose gel of PCR products representing (A)amplification of $700 \mathrm{bp}$ amplicons of universal 16SrRNA housekeeping gene of Vibrio species, (B) amplification of $737 \mathrm{bp}$ amplicons of collagenase gene of $V$. alginolyticus.

\section{Antimicrobial sensitivity test:}

The result of antimicrobial susceptibility test of virulent strain of $V$. alginolyticus showed that the bacterium was highly resistant to lincomycin $2 \mu \mathrm{g}$, streptomycin $10 \mu \mathrm{g}$, ampicillin10 $\mu \mathrm{g}$ and ampicillin/ sulbactam combination while it show intermediate sensitivity to naldixic acid $30 \mu \mathrm{g}$, polymyxin B $300 \mathrm{u}$, erythromycin $15 \mu \mathrm{g}$, tobramycin $10 \mu \mathrm{g}$, ciprofloxacin $5 \mu \mathrm{g}$, kanamycin $30 \mu \mathrm{g}$ and 
Table (5): result and interpretation of antibiotic sensitivity test:

\begin{tabular}{|c|c|c|c|c|c|c|}
\hline \multirow{2}{*}{$\begin{array}{l}\text { Antimicrobial } \\
\text { agents }\end{array}$} & \multirow[t]{2}{*}{ Symbol } & \multirow{2}{*}{$\begin{array}{l}\text { Disc } \\
\text { conc. }\end{array}$} & \multicolumn{3}{|c|}{ Diameter of inhibition zone } & \multirow[t]{2}{*}{ Result } \\
\hline & & & $\begin{array}{c}\text { Resistant } \\
\text { (R) mm } \\
\text { or less }\end{array}$ & $\begin{array}{l}\text { Intermediate } \\
\text { (M) } \mathbf{~ m m} \\
\text { range }\end{array}$ & $\begin{array}{c}\text { Sensitive } \\
\text { (s) mm or } \\
\text { more }\end{array}$ & \\
\hline Ampicillin & (AM) & $10 \mu \mathrm{g}$ & 14 & $15-16$ & 17 & 4.5 \\
\hline $\begin{array}{l}\text { Ampicillin/ } \\
\text { sulbactam }\end{array}$ & (SAM) & $\begin{array}{c}10 \mu \mathrm{g} \\
/ 10 \\
\mu \mathrm{g}\end{array}$ & 11 & $12-14$ & 15 & 6.5 \\
\hline $\begin{array}{l}\text { Piperacillin/ } \\
\text { tazobactam }\end{array}$ & (TPZ) & $\begin{array}{c}100 \mu \mathrm{g} \\
/ 10 \\
\mu \mathrm{g}\end{array}$ & 17 & $18-20$ & 21 & 24.5 \\
\hline chloramphenicol & (C) & $30 \mu \mathrm{g}$ & 12 & $13-17$ & 18 & 16.5 \\
\hline Gatifloxacin & (GAT) & $5 \mu \mathrm{g}$ & 14 & $15-17$ & 18 & 27.5 \\
\hline Ciprofloxacin & (CIP) & $5 \mu \mathrm{g}$ & 15 & $16-20$ & 21 & 17 \\
\hline lincomycin & (L) & $2 \mu \mathrm{g}$ & 11 & $12-16$ & 17 & No zone \\
\hline Gentamycin & $(\mathrm{CN})$ & $10 \mu \mathrm{g}$ & 12 & $13-14$ & 15 & 20 \\
\hline Kanamycin & $(\mathbf{K})$ & $30 \mu \mathrm{g}$ & 13 & 14-17 & 18 & 17.5 \\
\hline Tobramycin & (TOB) & $10 \mu g$ & 12 & 13-14 & 15 & 13 \\
\hline Erythromycin & (E) & $15 \mu \mathrm{g}$ & No zone & $<15$ & $>15$ & 14.5 \\
\hline streptomycin & (S) & $10 \mu g$ & $<11$ & $12-14$ & $>15$ & No zone \\
\hline Oxytetracycline & (TE) & $30 \mu g$ & 14 & $15-18$ & 19 & 20 \\
\hline Trimethoprim & (TMP) & $5 \mu \mathrm{g}$ & 10 & $11-15$ & 16 & No zone \\
\hline $\begin{array}{c}\text { Trimethoprim / } \\
\text { sulphamethoxazole }\end{array}$ & $(\mathbf{S X T})$ & $25 \mu \mathrm{g}$ & 10 & $11-15$ & 16 & 11.5 \\
\hline Polymyxin B & (PB) & $300 \mathrm{U}$ & 11 & $12-13$ & 14 & 11.5 \\
\hline Oxolinic acid & (OA) & $2 \mu \mathrm{g}$ & No zone & $<15$ & $>15$ & 23.5 \\
\hline Naldixic acid & (NA) & $30 \mu \mathrm{g}$ & 13 & $14-18$ & 19 & 17 \\
\hline Imipenem & (IPM) & $10 \mu \mathrm{g}$ & 19 & 20-22 & 23 & 34 \\
\hline
\end{tabular}


chloramphenicol $30 \mu \mathrm{g}$. it was also found that the bacterium was highly sensitive to imipenem $10 \mu \mathrm{g}$, oxolonic acid $2 \mu \mathrm{g}$, oxytetracyclin $30 \mu \mathrm{g}$, gentamycin $10 \mu \mathrm{g}$, gatifloxacin $5 \mu \mathrm{g}$ and piperacillin/ tazobactam combination. The inhibition zone is shown in (Fig 3).

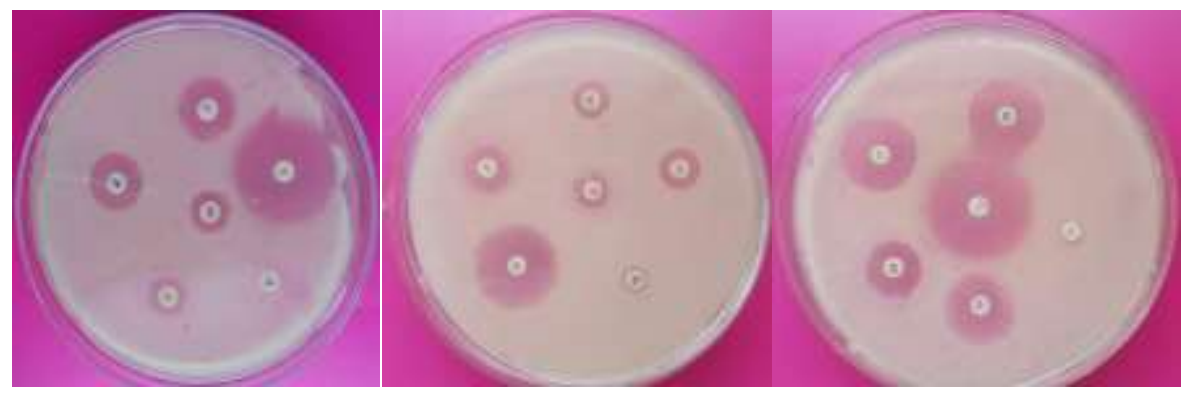

Fig (3): Inhibition zones of antibiotic susceptibility test.

\section{Discussion}

Bacterial diseases are the major constraint affecting production and sustainability of aqua-culture operation (Khalil and Abd El-Latif 2013). Vibriosis is the most common bacterial disease affecting Mariculture fishes worldwide causing severe economic losses. The obtained results of naturally infected fishes indicating disease problem and the clinical signs varied from dark coloration of skin with detached scales, and hemorrhage at the base of the fins with some erosion Which support the findings of El-Bouhy et al. (2016) and Al-Taee et al. (2017) in Mugil and Tilapia. Post mortem examination the fish revealed clear internal typical lesions. Internally there was congested friable enlarged liver and congested kidney (Fig1). These findings were agreed with those reported by Younes, et al. (2016); Abdel-Aziz et al., (2017) and Bluford et al. (2017). Bacteriological examination of isolated Vibrio species depends mainly on using TCBS agar as a selective media to differentiate between sucrose and non-sucrose fermenter colonies. The result of identification revealed that V.alginolyticus is sucrose fermenter showing yellow color. These finding were in lines with results obtained by Zulkifli et al. (2009); Shionda (2011) and Abdellrazeq and khaliel (2014). The result of biochemical identification showed that V.alginolyticus was oxidase, catalase, indole, methyl red and citrate test positive while they were Vogus Proskauer test negative ( Tab 1) and these finding go in parallel with Snoussi $\boldsymbol{e t}$ al., (2008) and Abu-Elala et al., (2016). The result of identification of 
V.alginolyticus by API (20NE) revealed about $99.1 \%$ probability with a code of 7447444 (Tab 2). These finding were agreed with result found by Martins et al., (2008); El-Bouhy, (2016) and Abu-Elala et al., (2016). The results of molecular identification of Vibrio isolates by using 16SrRNA results in PCR product with positive amplicons at 663bp as shown in Fig (2). And these results are agreed with Younes et al., (2016); You et al., (2016) and Abdelaziz et al., (2017). 16SrRNA gene was used for confirmation of biochemically identified vibrio species; however the result showed that this gene has low discriminatory power to differentiate closely related vibrio species that were nearly identical as V.parahaemolyticus and V.alginolyticus (Montieri et al. 2010, Younes et al. 2016). The specific identification of $V$. alginolyticus by using specific primer targeting collagenase gene resulted in PCR product with production of positive amplicons that were detected at 737 bp as shown in Fig (2). Similar result was obtained by Khamesipour et al. (2014); Moustafa et al. (2015) and El-Hady et al. (2015). The result showed that only one strain of V.alginolyticus produces positive tdh gene with positive amplicon at 373bp and this result is with agreement with Natividad-Bonifacio et al., (2013), Mustapha et al., (2013), and Hernández - Robles et al., (2016). Multiple sequence alignment of $16 \mathrm{~S}$ rRNA partial gene sequence of V.alginolyticus showed $99 \%$ identity with other Vibrio species recorded on gene bank with accession number (MG271844). The result for invitro sensitivity test of virulent strain of V.alginolyticus showed that the bacterium was highly resistant to lincomycin $2 \mu \mathrm{g}$, streptomycin $10 \mu \mathrm{g}$, and ampicillin $10 \mu \mathrm{g}$, ampicillin/ sulbactam combination. On the other hands, it show intermediate sensitivity to naldixic acid $30 \mu \mathrm{g}$, polymyxin B 300u, erythromycin $15 \mu \mathrm{g}$, tobramycin $10 \mu \mathrm{g}$, ciprofloxacin $5 \mu \mathrm{g}$ and chloramphenicol $30 \mu \mathrm{g}$. Also it was also found that the bacterium was highly sensitive to oxolonic acid $2 \mu \mathrm{g}$, oxytetracyclin $30 \mu \mathrm{g}$, gentamycin $10 \mu \mathrm{g}$, gatifloxacin $5 \mu \mathrm{g}$ and piperacillin/ tazobactam combination. This result was agreed with those of, Abdel-Aziz et al., (2013); Khaliel et al., (2014); Younes et al., (2016) and Hernández - Robles et al., (2016).

It could be concluded that V.alginolyticus is significant threat to Mugil Seheli aquaculture in Egypt. PCR is sensitive and accurate method for diagnosis of Vibriosis. 


\section{Acknowledgments}

We greatly appreciate the assistance of Dr. Mahmoud Saber Kelany; assistant lecturer, Marine Microbiology Lab, Marine Environmental Division, National Institute of Oceanography and Fisheries (NIOF) for his valuable support during the practical part.

\section{Reference}

Abdellrazeq, G. S. and Khaliel, S. A. (2014): Molecular 1f Characterization and Antimicrobial Susceptibility of Vibrios Isolated from Healthy and Diseased Aqua-cultured Freshwater Fishes; journal of Veterinary World vol: 7 iss: 8 pp586-593.

Abdel-Aziz, M.; Eissa, A. E.; Hanna, M. and Abou Okada, M. (2013): Identifying some pathogenic Vibrio/Photobacterium species during mass mortalities of cultured Gilthead seabream (Sparus aurata) and European seabass (Dicentrarchus labrax) from some Egyptian coastal provinces, International Journal of Veterinary Science and Medicine vol: 1 pp: 87-95.

Abdel-Aziz, M.; Ibrahem, M. D.; Ibrahim, M. A.; Abu-Elala, M.N and Abdel-moneam, D. A. (2017): Monitoring of different Vibrio species affecting marine fishes in Lake Qarun and Gulf of Suez: Phenotypic and molecular characterization, Egyptian journal of aquatic research (43): 141-146.

Abu-Elala, N. M.; Abd-Elsalam, R. M.; Marouf, S.; Abdelaziz, M. and Moustafa, M. (2016): Eutrophication, Ammonia Intoxication, and Infectious Diseases: Interdisciplinary Factors of Mass Mortalities in Cultured Nile Tilapia; Journal of Aquatic Animal Health, (28):3, 187-198.

Al-Taee, A. M. R.; Khamees, N. R. and Al-Shammari N. A. H. (2017): Vibrio Species isolated from farmed fish in Basra City in Iraq. J. Aquac. Res. Development, (8): 472-475.

Aly, S. M. (2009): Probiotics and aquaculture. CAB Reviews: Perspectives in Agriculture, Veterinary Science, Nutrition and Natural Resources, 4(074): 1-16.

Austin, B. and Austin, D. A. (2012): Bacterial fish pathogens: diseases of farmed and wild fish. 5th ed. Chichester, UK: Springer/Prazis Publishing.

Barbosa, M.C.; Jatobá, A.; Vieira, F. D. N.; Silva, B. C.; Mourino, J. L. P.; Andreatta, E. R.; Seiffert, W.Q. and Cerqueira, V. R. 
(2011): Cultivation of juvenile fat snook (Centropomus parallelus Poey, 1860) fed probiotic in laboratory conditions. Braz. Arch. Biol. Technol., 54(4): 795-801.

Bluford, J.; Gauthier, D.; Colasanto, M.; Rhodes, M.; Vogelbein, W. and Haines, A. (2017): Identification of virulence genes in Vibrio spp. isolates from the 2009 Bermuda reef fish mortality event. J Fish Dis (40):597-600.

Buller, N.B. (2004): Bacteria from Fish and Other Aquatic Animals: A Practical Identification Manual. CABI Publishing, Cambridge.

Cabello, F. C. (2006): Heavy use of prophylactic antibiotic $\$ 3$ in aquaculture: a growing problem for human and animal health and for the environment. Environmental Microbiology, (8): 1137-1144.

Carson, J; Higgins, M. J; Wilson, T. K; Gudkovs, N. and Bryant, T. N. (2009): identification of Vibrionaceae from Australian aquatic animals using phenotypic and PCR procedures Australian New Zealand standard diagnostic procedures, pp: 1-35.

Clinical and laboratory standards institute (CLSI, 2012): Performance standards of antimicrobial susceptibility testing; twenty-second informational supplements. CLSI document M100S22. Clinical and Laboratory Standards Institute, 940 West Valley Road, Suite 1400, Wayne, Pennsylvania 19087-1898 USA.

Costinar, L.; Herman, V.; Pascu, C.; Marcu, A.; Marcu, A. and Faur B. (2010): Isolation and characterization of Vibrio alginolyticus and pasteurella from Siberian Sturgeon (Acipenser Baerii). LUCRĂRI STIINłIFICE MEDICINĂ VETERINARĂ VOL. XLIII (1),TIMISOARA.

El-Bouhy, Z.; El-Nobi, G.; El-Murr, A.; Abd El-Hakim, S. (2016): Study On Vibriosis In Mugil Capito In El-Dakahlia And Damitta Governorates, Egypt. Abbassa Int. J. Aquat. 9 (1).

El-Hady, M. A.; El-khatib, N. R. and Abdel-Aziz, E. S. (2015): Microbiological studies on Vibrio species isolated from some cultured fishes. Animal Health Research Journal, 3(1):12-19.

Esposito, A.; Fabrizi, L.; Lucchetti, D.; Marvasi, L.; Coni, E. and Guandalini, E. (2007): Orally administered erythromycin in rainbow trout (Oncorhynchus mykiss): residues in edible tissues and withdrawal time. Antimicrobial Agents Chemotherapeutics (51):1043-1047.

Hernández - Robles, M. F.; Álvarez-Contreras, A. K.; JuárezGarcía ， P.; Natividad-Bonifacio, I.; Curiel-Quesada, E.; 
Vázquez-Salinas, C. and Quiñones-Ramírez, E. I. (2016): Virulence factors and antimicrobial resistance in environmental strains of Vibrio alginolyticus. International Microbiology 19(4):191-198.

Khalil R. H. and Abd El-Latif H. M. (2013): effect of Vibrio alginolyticus on Mugil Capito. J. Arabian Aquaculture.Soc.8 (1), 193-204.

Khaliel, S. A.; Abou-Akkada, A. S. and El-Hoshy S. M. (2014): Molecular studies on Vibrio species isolated from imported frozen fish. Global Veterinarian, 12 (6): 782-789.

Khamesipour, F.; Noshadi, E.; Moradi, M.; Raissy, M. (2014): Detection of Vibrio spp. in shrimp from aquaculture sites in Iran using polymerase chain reaction (PCR). Aquaculture, Aquarium, Conservation and Legislation International Journal of the Bioflux Society, Volume 7, Issue 1: 1-7.

Levy, S. B. (2001): Antibiotic resistance, consequences of infection. Clin. Infect, Dis.(33):S124_S129.

Martins, M. L.; Mouriño, J. L. P.; Fezer, G. F.; Buglione Neto, C. C.; Garcia, P.; Silva, B. C.; Jatobá, A. and Vieira, F. N. (2008): Isolation and experimental infection with Vibrio alginolyticus in the sea horse, Hippocampus reidi Ginsburg, 1933(Osteichthyes : Syngnathidae ) in Brazil. Braz. J. Biol. vol.70 no.1, pp. 205-209. São Carlos.

Montieri, S.; Suffredini, E.; Ciccozzi1, M. and Croci, L. (2010): Phylogenetic and evolutionary analysis of Vibrio parahaemolyticus and Vibrio alginolyticus isolates based on tox Rene sequence. NEW MICROBIOLOGICA, 33, pp. 359-372

Moustafa, M.; Eissa, A. E.; Laila, A. M.; Gaafar, A. Y.; Abumourad, I. M. K. and El-gendy, M. Y. (2015): Investigations into the Potential Causes of Mass Kills in Mari-Cultured Gilthead Sea Bream (Sparus-aurata) at Northern Egypt. Research Journal of Pharmaceutical, Biological and Chemical Sciences, 6 (1): 466- 477.

Musa, N. and Wei, L. S. (2008): Bacteria attached on cultured seaweed Gracilaria changii at Menga bang Telipot,Terengganu. Academic Journal of Plant Sciences. 1 (1): pp. 1-4.

Mustapha, S.; Mustapha, E. M. and Nozha, C. (2013): Vibrio Alginolyticus: An Emerging Pathogen of Foodborne Diseases. International Journal of Science and Technology Volume 2 No. 4, pp. 302-309. 
Natividad-Bonifacio, I.; Fernández, F. J.; Quiñones-Ramírez, E. I.; Curiel-Quesada, E. and Vázquez-Salinas, C. (2013): Presence of virulence markers in environmental Vibrio vulnificus strains. J Applied Microbiol (114):1539-1546.

Nelson, J. S. (2006): Fishes of the world, 4th Ed. New York, Wiley, (601).

Noga, E. J. and Dvm, M. S. (2010): Fish Diseases: Diagnosis and Treatment. Iowa State University Press, Ames, Iowa.

Ransangan, J.; Khor, L.; Imm, L.; Lal, T. M. and Sade, A. (2013): Phenotypic characterization and antibiotic susceptibility of Vibrio spp. Isolated from aquaculture waters on the west coast of sapgh, Malaysia, International Journal of Research in Pure and Applied Microbiology vol 3, No. 3, pp. 58-66.

Salinas, I.; Dı'az-Rosales, P.; Cuesta, A.; Meseguer, J.; Chabrillo'n, M.; Morin igo, M. A.and Esteban, M. A.' ngeles. (2006): Effect of heat-inactivated fish and non-fish derived probiotics on the innate immune parameters of a teleost fish (Sparus aurata L.) Veterinary Immunology and Immunopathology (111): 279-286.

Shinoda, S. (2011): Sixty Years from the Discovery of Vibrio parahaemolyticus and Some Recollections. Biocontrol Science, (16): 129-137.

Snoussi, M.; Hajlaouia, H.; Noumi, E.; Zanetti, S. and Bakhrouf, A. (2008): Phenotypic and genetic diversity of Vibrio alginolyticus strains recovered from juveniles and older Sparus aurata reared in a Tunisian marine farm. Annals of Microbiology journal, vol.58, No. 1, pp.141-146.

Tarr, C. L.; Patel, J. S.; Puhr, N. D.; Sowers, E. G.; Bopp, C. A. and Strockbine, N. A. (2007): Identification of Vibrio isolates by a multiplex PCR assay and rpoB sequence determination. Journal of Clinical Microbiology, (45):134-140.

Todar, K. (2005): Vibrio cholera and Asiatic cholera, text book of bacteriology.net/ cholera.

You, K. G.; Bong, C. W. and Lee, C. W. (2016): Antibiotic resistance and plasmid profiling of Vibrio spp. in tropical waters of Peninsular Malaysia, Environmental Monitoring and Assessment188 (3):171.

Younes, A. M.; Fares, M. O.; Gaafar , A. Y. and Mohamed, L. A. (2016): Isolation of Vibrio alginolyticus and Vibrio vulnificus Strains from Cultured Oreochromis Niloticus Around Qarun Lake, Egypt. Global Veterinaria 16 (1): 01-05. 
Zulkifli, Y.; Alitheen, N. B.; Son, R.; Yeap, S. K.; Lesley, M. B. and Raha, A. R. (2009): identification of Vibrio parahaemolyticus isolated by PCR target to the toxR gene and detection of virulence genes. International Food Research Journal (16): 289-296. 


\section{عزل وتصنيف ومقاومة المضادات الحيوية لفبريوالجينوليتكس المعزولة من المن المبرئ

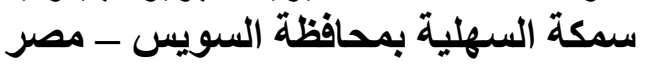

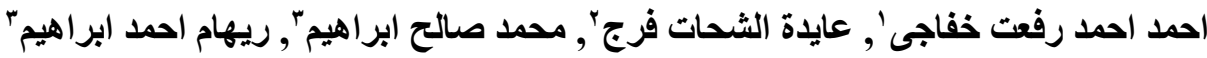
1 ـ قسم البكتريولوجيا, المناعة والفطريات, كلية الطب البيطري جامعة قناة السويس. Y بمعمل البيوتكنولوجي, شعبة البيئة البحرية ,المعهد القومي لعلوم البحاروالمصايل (الاسكندرية).

ץ-معمل الميكروبيولوجي , شعبة البيئة البحرية, المعهد القومي للعلوم البحاروالمصايد (الاسكندرية).

\section{الملخص العربى}

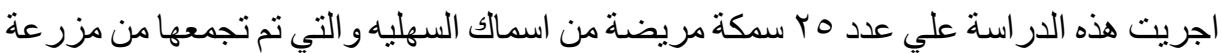

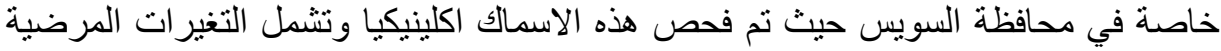

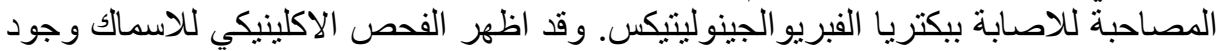

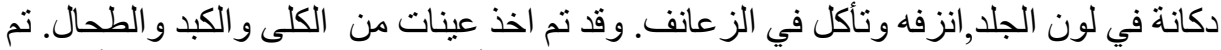

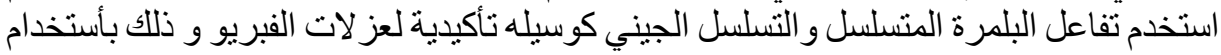

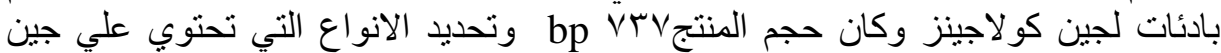

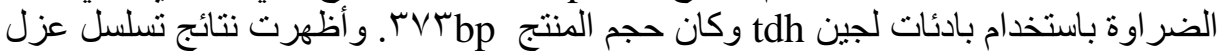

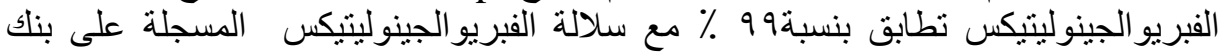
الجينات (accession number MG271844). أظهر اختبار الحساسية أن البكتيريا كانت عالية المقاومة لللينكوميسين rمج ، الستربتو ميسين · (مجم ، أمبيسيلين · ( مجم ، تريميثوبريم

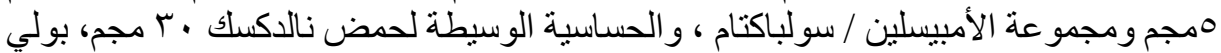

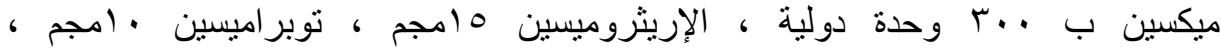

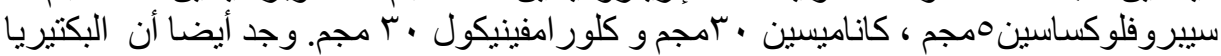

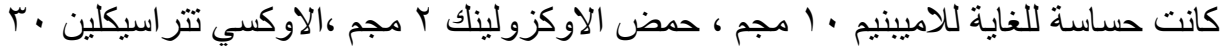

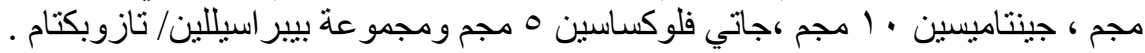

